\title{
Presence of Witchcraft in the Contemporary Udmurt Village
}

\author{
Nikolai Anisimov \\ e-mail: nikolai.anisimov@folklore.ee; kyldysin@yandex.ru
}

\begin{abstract}
Based on the author's fieldwork materials (2007-2021) as well as on sources from scientific literature, this article examines how wizards and witches are seen in today's Udmurt village. It analyses the characters of these magic specialists within the framework of folk understanding. It explains their role, their activities and their status in the village community, it presents magical methods of combat and selfdefence, as well as some trends of late years. The latest field materials show the present narratives about people who master magic strength and secret knowledge, updating the research. This new material highlights the innovative character of the research. The results allow us to say that alongside traditional understandings, there are relatively new cultural phenomena appearing at practically all the levels of the village perception of wizards and witches. The changes in the present world and the 'fashion' for magic knowledge give the village community a new focus on tradition. For example, people think that electricity cables, as well as mobile phone networks and satellite antennas, have started to disturb the flights of wizards and witches, and elements from other cultures have been added to magic apotropaic repertoire, etc. Thus, this article follows what is happening presently in Udmurt village communities with regard to the cultural mythical phenomena surrounding the worldview of magical specialists. The results of this study may be a useful basis for further research, and it will be important to observe the further evolution in the village reception of these phenomena.
\end{abstract}

Keywords: Udmurts, witchcraft, witches, wizards, worldview 
The topic of witchcraft is in all cultures of the world both an actively cultivated issue and a very intimate one, and it is also the case in Udmurt culture. We can say that the belief in magic, especially in people who are loaded with supernatural force, is still very much alive in particular Udmurt villages. In this article, I rely on materials from my fieldwork (further: FWM) between 2007 and 2021, mainly among the southern and eastern Udmurt; moreover I also rely on my personal experience, as I am a bearer of the researched culture. I rely heavily on interviews with people who are mastering what we call 'sacred knowledge' (healers, wizards, witches, etc.). I must highlight that because of the intimate nature of the topic as well as for ethical reasons, some informers expressed the wish to remain anonymous. I compare the results of my fieldwork with data on this issue from existing publications (for example, Emel'yanov 1921; Vladykina 1992; Minniyakhmetova 1996; Zaytseva 2003; Vladykina 2004; Vladykina 1997; Panina 2014). I concentrate here on contemporary narratives about witchcraft and the characters of wizards and witches, as well as relations between the village community and these magic specialists.

\section{The characters of wizards and witches}

According to folklore narratives, wizards and witches show almost no external differences to other people, but they have the gift of metamorphosis and are loaded with supernatural forces. According to my informants, wizards and witches master some secret knowledge, which is clearly reflected in the vernacular words that describe them in the local communities: todis'/todis'-valas'/todemez van' 'knower'/'knower-understander'/'one who has knowledge'. Udmurt folklorists Tatiana Vladykina and Galina Glukhova distinguish four levels of knowledge and magical skill in traditional Udmurt culture, from the weaker to the stronger. In this hierarchy wizards occupy the first, lowest, step (for more details, see Vladykina 2004: 
102; Vladykina, Glukhova 2011: 132), althoug this does not in any way diminish their status in the local community.

The Udmurt consider that the most skilled specialists in magic are the Mari and the Gypsies, i.e. ethnic Others. The Udmurt avoid having close contact with these people as they are afraid of becoming victims of their magical attacks $\left(\mathrm{FWM}^{1}\right)$. However, there are materials showing that the Udmurt's ethnic neighbours are, in turn, afraid of them, for example Russians, Tatars, Bashkirs. Thus, eastern Udmurts think that Tatar and Bashkirs are afraid of them because they think the Udmurt have mastered special magical strength and know how to curse:

Udmurtez kuzhmo shusa malpalo. Ad'amiyez söryny bugato shuysa. Udmurtlen danakges shuysa malpalo, todemzy. Kyz'y shuod, inkuaz'en matynges-a. Udmurt kargashiz ke no, kargashemez us'oz. Soin tin’i kyshkaloges in’i soos.

[The Tatar and Bashkir] think the Udmurts are strong [in magic]. That they are able to damage people. They think the Udmurts have more [magical] knowledge. How do you say, [the Udmurt] are close to nature, are they? When an Udmurt curses you, the curse functions. Therefore, they are afraid $\left(\mathrm{FWM}^{2}\right)$.

As an Udmurt, I experienced a similar situation in Izhevsk in 2011 when I was in a taxi talking with a friend in Udmurt. This produced a negative reaction in the driver, an ethnic Russian. He said rudely that we must not speak in a language he does not understand, and that all Udmurts are wizards who know only how to curse people. These examples reflect the imagined connection between native peoples and magic, in this case witchcraft (Panina 2014: 90). Ol'ga Belova observes about this aspect of culture: "The assessment of 'others' as enemies, dangerous beings, goes back to archaic beliefs that all that comes from outside and does not belong to the closer 
community circle are representatives of the other world and are gifted with supernatural properties" (Belova 2009: 581).

According to my informants, one can recognise wizards and witches either by their behaviour or by some external features:

- Witches do not allow anybody to look in the eyes, they react to visual contact by immediately turning their glance aside $\left(\mathrm{FWM}^{3}\right)$;

- In the eyes of the wizard or of the witch, everything is reflected from the head down ( $\mathrm{FWM}^{4}$; Vladykina, Glukhova 2011: 27);

- In his/her eyes and mouth, one can see a blazing fire $\left(\mathrm{FWM}^{5}\right)$;

- Witches and wizards have no shadow (FWM ${ }^{6}$; Vladykina, Glukhova 2011: 27);

- If you call them witch or wizard, they are very offended and angry $\left(\mathrm{FWM}^{7}\right)$; “...witches do not like gossip and they punish harshly those who spread rumours about them” (Minniyakhmetova 1996: 259);

- Under the influence of alcohol, they rave and show defiant behaviour - vedin'zy uzate/ulate - "the witchcraft force provokes" $\left(\mathrm{FWM}^{8}\right)$;

- They insist that a person tastes a dish or drink, in order to harm them through this food ( $\left.\mathrm{FWM}^{9}\right)$;

- A wizard will not eat a hunk of bread with the crust turned towards him (Vladykina 1997: 241), etc.

According to Udmurt beliefs, one can recognise a wizard thanks to some actions connected with the other world, the world of evil spirits. For example, when a witch or a wizard has entered the house, one must protect oneself in the following ways: put near to the door a broom with the handle downwards; overturn a container; put a piece of clothing on backwards; offer a hunk of bread with the crust turned towards the wizard, etc. It is also possible to use apotropic objects, for example, stick in the doorjamb a needle without an eye, or a knife or pair of scissors; pour salt, ashes or 
hot embers on the threshold where the witch or wizard trod; keep a bit of bread handy, attach a horseshoe to the threshold (FWM ${ }^{10}$; Vladykina 1992: 127-129; Vladykina 1997: 241). Wizards and witches cannot manage with a world 'upside down', constructed by people with the help of amulets, so they reveal themselves. In Udmurt there are special terms connected with the discovery of these characters - vedin'en/veginen kuton 'catching someone in witchcraft', vedin'ez/veginez pytsan 'to shut out a witch or wizard', vedin'ez/veginez tupaton 'to correct a witch or wizard'. I have in my material a fair amount of this kind of narrative. Here are some of them:

Ogpol vannapalan dyr"yaky, pysytem ven'ös d'yr d'yle ponysa, potis'tem kariz. Ug pot n’i, puke no puke. Khusnidiyan kenakez... Ug pot n’i. Murt pyriz no, biziz no, potiz no koshkiz. Ug poto n'i, pe, soos. Oz'y todyn lue vedonlykze. Pysytem ven' ke uan', ponis'kod no uchkis'kod, poto na taos, ug n'i-a. [...] So Arkadiyen Van'aos serekdzh'yalo inde Khusnidiyan kenakez pukytis'kom shuysa.

Once, when we were at the top of the street, [a man] having affixed over the door a needle without an eye, he made the witch unable to get out [of the house]. So she does not leave, she just sits and sits. Aunt Khusnidiyan ... And she does not leave. Another person entered, and [the witch] ran and went into the street. They did not go out. This way it is possible to reveal their witchcraft. If there is a needle without an eye, you put it and you observe, whether they go out or not. [...] They laughed, these Arkadiy and Vanya, they managed to oblige aunt Khusnidiyan to do it (FWM $\left.{ }^{11}\right)$.

Val dagayez no pono kad' no... olo, ös kusype. [...] Val daga, pe, poni no, todemez, pe, vylem kad'. Pyre, pe, val no, adzh'dzh'iz, pe, val dagame no, öz, pe, pyry n’i. 
They also put a horseshoe, it seems... Or at the threshold, at the door. [...] A horseshoe, they say [the master of the house] he put it, yes, [the man who came in] has knowledge, it seems. He entered, they say, and then he saw my horseshoe and did not come in $\left(\mathrm{FWM}^{12}\right)$.

In most of the stories, the person asks that her/his secret be kept. However, according to some witnesses, the discovered wizards or witches might take revenge on the person who uncovered them by causing their premature death $\left(\mathrm{FWM}^{13}\right)$. According to other data the witch or wizard cannot leave the place of their magical imprisonment until they have spilled their own blood (FWM $\left.{ }^{14}\right)$. It is also notable that someone could be suspected of witchcraft by avoiding magical obstacles set by wizards or witches, or if by chance this person is in the wrong place at the wrong time. Such people are immediately marked as connected to the magical sphere. For example, one informant told me that because of something that happened to her, she was identified as a witch. One night she came back after a birthday party in the village and met a couple at a crossing. After a short conversation, they parted. When she came home, she understood that this meeting had taken place at midnight. The next day she learned from a friend that the couple had visited a healer, who had asked them to go out at midnight at the crossing in order to be free of an enchanted bundle, after which they would meet the witch who was sending them their misfortune. This woman was so disturbed that that she went to see them, apologised, and explained that she was no witch. Later it became clear that they had not exited their home at midnight, but at a quarter to midnight. The informant concluded that if they had gone out exactly at midnight, they would have met the witch, and she would not have happened to be in such a suspicious position $\left(\mathrm{FWM}^{15}\right)$.

In many narratives, we note the ability of the wizards and witches to metamorphose. They can adopt whatever form they 
wish, anthropomorphic, zoomorphic, ornithomorphic and even transform into natural phenomena. Some informants suppose that what shifts shape is the soul of the wizard or witch, while others think that both the soul and the body metamorphose. Let us briefly observe both cases.

Anthropomorphism. According to the tradition of the southern Udmurt wizards and witches can transform themselves into any person and thus act upon their victims. Let us get acquainted with an example reported by a woman. In her story, one morning, before dawn, a witch in the form of her mother-in-law (who at that time was already at work) wanted to go near to her child, thinking of doing something to him. My informant, with her husband and the child, were still in bed. Suddenly, the child started to cry and would not stop, while in the yard the dog howled. The woman saw her 'mother-in-law' come from behind of the oven and move towards her. When the woman addressed her, the witch went back to the oven, and thus twice. The third time, the witch under the guise of the mother-in-law was already quite close to the child, so the woman started shouting. Then the witch fled back into the oven and disappeared. In the house, everybode woke up. Then the great grandmother, who was still alive, did something and the child calmed down. The great grandmother explained that witches were able to transform into acquaintances and thus harm people; they ask Inmar ${ }^{16}$ for permission to take a soul through the howling of dogs $(F W M)^{17}$. People also believe that a wizard or witch is able to send a curse through an acquaintance, without that person suspecting anything $\left(\mathrm{FWM}^{18}\right)$. Tatiana Minniyakhmetova presents some curious data about the eastern Udmurt: "if a witch goes to 'work' in the form of another person, and she meets someone, this person, undoing his/her buttons or unknotting her clothes, may bring her back to her original form. As a result, she must give the name of the person to whom she was going, or whom she had already managed 
to curse, and after this the person who caught her is able to free the victim from the curse (Minniyakhmetova 1996: 259).

Zoomomrphism. According to Udmurt belief, wizards and witches can turn into different animals. The most frequent are cats (both male and female), pigs, dogs, ewes, rams, goats and bucks. Here are some narratives about this kind of metamorphosis collected during my fieldwork:

Mil'am atay taka vyle puks'ysa vetlem. Ta takaez pyrtono shuysa Askar agayen puks'il'l'am no... Puks'em no vylaz, takayez mynon s'ainyz evölly, pe, potiz.

Our father rode a ram. He decided to bring him [to the yard]. He and uncle Aksar they sat [on the animal] and... [Father] was riding him, but after a little while, the ram disappeared $\left(\right.$ FWM $\left.^{19}\right)$.

Bazare mynis'yos kölyny pyril'l'am, olo, Vuzh Mön'yala, olo, Dzhik"yala. Kytynze ug tos'ky n'i. [...] Pyril'l'am kyshnomurten kyknazy no. Ey! nylynyz pyril'l'am kölny. Tare uyshor, pe, vuiz in'i no tare nylyz, pe, börde: "mynam s'iyeme pote", pe, shue. Bon, pe, shue maray, "yzh karis'kysa myn ay otsy, soos dory”. Kin'e ke no vera. [...] Mynem, vetlem. "Mynam soye s'iyeme ug luy", pe, shue. Sere nosh kuke soku vetlem. [...] Sere ogezles'-ogez kylysa, vs'o romno kin'e so kosem, vs'o romno so ad'ami kulem.

Those who went to the market arrived, perhaps it was at Old Mon'ya, perhaps at Old Burozhik. I do not remember where. [...] They entered the house, together, with a woman. Oh! They came to spend the night with their daughter. Then it was midnight and the daughter, they say, weeps: "I want to eat!" she says. So, she says, "Turn into a lamb, and go there, 
to them". And they mention someone. [...] She went. "I can't manage to eat him/her", she says. Then she went again somewhere. [...] Then she heard from someone [that the rumour went] that whoever she punished, this person died $\left(\mathrm{FWM}^{20}\right)$.

Id'ot sobaka, raz, raz, id'ot. Esl'i po sl'edu poyd'osh, on vstayot $i$ ukhodit chelovekom. [...] Potom id'ot koshka i pod nogi l'ez'et. Inogda tak sil'no meshayet po put'i, i nastupaesh' na khvost il'i cho. I tut chelovecheskim golosom govorit: "Zachem men'a b'yosh?'21

A dog walks, he walks. If you follow his footprints, he stands up and goes away as a person. ... Then a cat walks and it crawls under your legs. Sometimes he disturbs you so much that you tread on its tails or something. And then it speaks with a human voice: "Why do you beat me?" $\left(\mathrm{FWM}^{22}\right)$.

Pichapay nosh vera val. Püny, pe, lykte shydsa bertyky. Vü duryn shydo val az'lo. Püny, pe, lykte, taz'y ik tankaosyz “shyl'k-shyl'k-shyl'k", pe, kare tan'taz'y tan'i. Biz'is'kod es' in'i tan'taz'y tin'i. Pichapay gulbechti, pe, pyri, korkaz'ti no, pe, öy tuby n’i kyshkasa.

My aunt told me the following story. A dog, they say, goes, when they went home after the [evening] games. Before, they played by the water. The dog goes, they say, and the monist (breast adornment made from coins) jingles "shyl'k, shyl'k, shyl'k". You run so. My aunt entered through the cellar, she did not pass through the porch, she was so frightened $\left(\mathrm{FWM}^{23}\right)$.

Let me note that in spite of their animal form, wizards or witches retain their human properties: they do not loose their ability to speak with a humain voice, and they reveal their identity through 
attributes of the human world (for example jewellery). Udmurt folklorist Tatiana Panina observes that a magic specialist turned cat keeps his/her human teeth (Panina 2014: 36). And people think that the older the witch or wizard is, the bigger animal he/she chooses to transform into, for an older person is no longer able to be as quick and tough as a cat $\left(\mathrm{FWM}^{24}\right)$.

Ornithomorphism. The largest number of stories are connected with the transformation of wizards and witches into birds, either domesticated or not: geese, hens, sparrows, tits, swallows, and pigeons:

Mon kinen povaryn uzhay, vit' chasyn dzhyt tubis'ko, pe, kyshnomurt. Lymy, pe, us'e n'i, o-o-o. Tare kyti ke övöl az'am, pe, sach gyne dzh'adzh'eg us'iz. Tare, pe, uchkis'ko n'i, bon mar ta tatshe, kytshe-mar dzh'adzh'eg'yos na. Raz, da kyshnomurt, pe, kyldiz, o-o-o. "Nokinly no en vera, mon tynyd van'ze s'oto" shuiz no pedzh'dzh'iz, pe.

A woman [told me], with those with whom I worked as a cook: "I went [from work] at five in the evening. It was snowing, it was. Suddenly before my eyes a goose fell. Now I looked, which geese? Suddenly a woman was [in front of me], so she was." "Do not tell anyone, I will give you whatever you want", she said and fled away $\left(\mathrm{FWM}^{25}\right)$.

It is not seen as a good omen if a bird flies into the house or the sauna:

Informant 1: Mi se Savin Ol'apay shukom, o-o-o. Uramamy..., kuliz in'i so kyshnomurt... Se mi vedin shukom, y-y-y. [...] Guzhem kuaz', ognam, y-y-y, korkan. Korkamy vuzh al'i, main ay, guren. Kyk etazh"em korka. I, so sokemeti pyryny kule uk. Mon al'i ke no paymis'ko. [...] So mur"yoti us'ysa dzh'ol'gyri... Mon pervyy sytshe kual'ekti. [...] Kak dzh'ol'gyri us’iz. So 
s'öd-s'öd sues' luemyn, y-y-y. Kyk gyne pichiyes' uknoosmy. I, srazu uknoye tash gyne shukkis'kiz. So ves'su paz'gis'kiz, $y-y-y$. [...] Kokas'ke, kokas'ke, kokas'ke, potyny vyre. A mon todis'ko anaylen veramys'tyz, so oz'y pyrem umoyly övöl dzh'ol'gyri pyrem mur'yoti. Mon sobere main ke no kymay so dzh'ol'gyriyez. I byz'sa memey dory, so kytyn ke no azbaryn. [...] Vay ay, pe, Oriyez kes'kom, tshuzhapez. [...]

Informant 2: Ya, mon s'ures vyle sulti no dzhyny mugorze otchy kari, dzhynyze tapalaz kari. [...]

Informant 1: Tshukaz'eyaz-a mar-a opet' achim ik tupay, $y-y$-y. Tabere so Savin Ol'apay... So dotovo chork-chork vetle val. Olomar uknoye uchkyny shed'ti no, kin ke no oti vyleti vas'ke no "kin bon meda sytshe vis'is' kyshnomurt vas'ke?" shuis'ko. Ves' kongyr-kongyr gyne, y-y-y. [...] Tare mateges vuiz no, Oste! bon so Savin Ol'apay uk. Tare mon paymi. [...] Ukno pas' guzhem, y-y-y. I so mil'am kapkaz'amy vuiz no, $y-y-y$, “t'fu!" s'aldzh'is'kiz mar ke byddzh'a, "vir yuis'yos!" shuiz no koshkiz.

Informant 1: We call her aunt Savin Ol'a, so it is. In our street... this woman already died... We call her a witch, so it is. [...] In summer, [I am] alone, am I not, at home. Our home is an old house, with, what is it, an oven. A two-storey house. And look, he managed to fly so far. I am surprised even now. [...] A sparrow falling through the chimney... At the beginning, I was so frightened... When the sparrow fell. He was covered in soot, he was entirely black, so it was. We have only two small windows. And immediately it collided with the glass. Even the soot spread around, so it was. [...] It hits, hits, hits, trying to fly away. But I know that, according to my mother, such an intrusion is not a good omen - when a sparrow flies in through the chimney. Then I somehow 
covered this sparrow. And I ran to my mother-in-law, she is in the yard somewhere. [...] Come on, she said, let us call aunt Irina.

Informant 2: There, I was standing on the road, and [breaking up the sparrow] I threw half of the carcass on one side and the other on the other side [of the road]. [...]

Informant 1: The next day, again I was [at home] again, so it was. And now this aunt Savin Ol'a... [Before] she walked very straight. [I] looked out of the window, somebody is coming down the street and "strange, who is this sick woman who is walking?", I say [to myself]. [She walks] hunched over, so she did. [...] Now she comes closer and, oh my God! It is aunt Savin Ol'a! Now I was surprised. [...] In summer, the windows are open, so it is. She came to our gate, she did, and she spat loudly "t'fu!" and she said "Blood-drinkers!" and went away $\left(\mathrm{FWM}^{26}\right)$.

The unauthorised intrusion of elements from the natural world into the human sphere is everywhere a dangerous phenomenon with undesirable consequences ${ }^{27}$, and in this case, it is accompanied by the dire activities of wizards or witches.

Natural phenomena. According to Udmurt legends, wizards and witches may transform into a whirlwind, a sudden and strong blast, flying fireballs, a fire snake, etc.:

Poyekhal'i domoy, mama s papoy i ya. Mama s'ela vpered'i, na loshadke... Zimoy zhe, na sankakh. Vot, tol'ko vyshl'i on'i i loshad' uzhe nachala furkat'. S vorota vyshl'i on'i, i loshad' nachala furkat'. Ekh! Babushka zhe govorila: "Davayt'e nochevat'. Nochuyt'e, n'e ezdit'e uzh, utrom poed'et'e”. N'et, ot'ets n'e slushal. Vpered'i okazyvayets'a u nikh, cherez rechku, 
tam Kalmiyar-Baltachevo pereyt'i nado. Do rechki, uzhe vpered'i u nikh igrayet mal'en'kiy ogon'. Vot tak krut'its'a, id'ot. On'i edut i ogon' krut'its'a vpered'i. A loshad'vs'o-taki furkayet $i$ furkayet. E-e-e, babushka skazala: "N'e ezd'it'e noch'yu." N'e slushal'i. Obratno razvernul'is' iv Kalmiyarovo vernulis'. [...] Vot, [mestnyy koldun] Shaybak n'e pust'il. ${ }^{28}$

We went home, mother, father and I. Mother sat ahead, on a horse... It was winter, in sledges. So, we had just departed and the horse started to snort. Oh! Our granny said: "Come on, spend the night here. Sleep here, don't go, you'll go in the morning". But no, father did not pay attention. Ahead of them, over the river, we must cross Kalmiyar-Baltachevo. Before the river, ahead of us, there is a small fire playing. It turns and moves. We go on and the fire turns in front of us. And the horse continues to snort and snort. Eh... granny said: "Do not travel at night." We didn't listen. We turned around and went back to Kalmiyarovo.... That's it, [the local] wizard Shaybak did not allow us to leave (FWM $\left.{ }^{29}\right)$.

Kyar, anay kunoke mynem no Nurtda kenaken bertil'l'am, o-o-a. Soye bon marym shuizy es' in'i... Kyar pyrim no, pe, vydi. Soin, pe, bertim. Berti no, tan'taz'y seregti "shart!", pe, shuiz no, tyl, pe pyriz. Lyktiz no Nurtda, pe, vyzhiye sultiz. Sobere anay soye vedon shuiz in'i.

There, mother went visiting and came back with aunt Nurtda, so it happened. About her they told the same story ... We entered and, there [mother] was lying. With her, we went back home. [Mother] came back home and behind the corner "shart!", we heard and a fire just flew off. Nurtda came to me, and stood by me. After that Mother called her a witch $\left(\mathrm{FWM}^{30}\right)$. 
In the Udmurt folk worldview, whirlwinds can be the avatars of strong wizards or witches and confrontation with them does not bode well. Therefore, when meeting a whirlwind or a strong blast people utter a protecting verbal formula: tire-purte kiyam! 'My knife, my axe into my hand!' or tire-purte bordam! - 'My knife, my axe to me!' (Anisimov 2017: 179). According to some narratives, a witch or wizard to whom a person turned with complaints unexpectedly declared that this person had run into a curse that the witch or wizard had blown onto the wind $\left(\mathrm{FWM}^{31}\right)$.

One may recognise a wizard or a witch because of their unnatural behaviour under their new form. For example, if a goose flies at night or fearlessly follows a person, if a cat walks on its hind legs, a pig tries to enter the house, a lamb turns around a person, a hen cries like a rooster and so on. The village community interprets these as attempts made by a magical enemy, therefore, in order to discover the metamorphosis, they submit the animal to physical violence (beating, chopping, cutting of limbs, scalding, burning, etc.). Further, they wait kytys' no kytshe ivor kylis'koz, i.e. 'wherefrom and which news comes [as gossip]' (FWM $\left.{ }^{32}\right)$. People expect that after physical injuries the wizard or witch will fall ill and so for some time will not appear to others, thus revealing his/ her magical art. Some stories about this topic:

Bertis'ko, pe, marymyn, az'yn, uramyn, pe, kochysh kyk pyd dzh'ylaz, pe, sultiz i kyk pyd dzh'ylaz, pe, lykte shore. Shullasa, kyrdzh'asa, pe, bertis'ko. Syre kyshkasa, pe, kes'as'kis'ko. I syreaz voobshche zhugil'l'am so kochyshez. I so lusa potem peres' odig ad'ami mil'am gurtis', pr'amo seregyn so. Pisey lusa, pe, potem oz'y. Kutsa, pe, zhugil'l'am soye. Sobere so peres'vyrdzh'ylyn bygatytek kulon kyale vuem.

On the way home, and, ahead, in the street, a cat stood up on her hind legs and walks after me. Whistling, singing, I am going home. Then, out of fright, I shout. And later, 
they beat this cat. It turned out to be an old woman from our village, right on the corner (she lived). She turned into a cat, and she went out in that guise. She was caught and beaten. After that, she was not able to move anymore and lied until she died $\left(\mathrm{FWM}^{33}\right)$.

Naprimer, ton shydysa, pe, bertis'kod, o-o-a, uin, ognad. Az'tid pars', pe, vetle, o-o-a. Ton soye shukkis'kod no katyges karysa main ke soin, so shukaz'eyaz il'i maiz ke pydyz chute il’i kiyyz mar ke lüe. Oz'y todmany lüe. I, dzh'a demen küz'a kutid ke, zhugid ke, so "mon ta, mon", pe, shue sobere so murt.

I suppose after [evening] games, you go back home thus, alone in the night. In front of you, a pig walks just so. You beat it with something hard, and the next morning she (the witch) limps or there is something with her arm. In this way, one may know. And, if you catch them when they gather, if you beat her, "it's me, me", speaks this person $\left(\mathrm{FWM}^{34}\right)$.

Piseyen, pe, nerad lui. [...] Tubi, pe, no, olo, ukvaten, olo, san'egen shuiz. So piseyez, pe, kuti. S’inmaz, pe, byshkaltis'kem. Syre meshoke, pe, poni. [...] Syre so s'in'tem pukiz. Mon ik tupatysa oz'y luiz shuiz Natal'l'a.

She was fed up with the cat. [...] She went up [to the attic], with an oven fork, or with a pitchfork, she said. This cat, she caught it. She stabbed its eyes. Then she threw it in a sack. [...] Then he [the wizard], remained blind. After my (lit: correction, 'lesson', 'punishment'), [he] remained [blind], said Natalya $\left(\right.$ FWM $\left.^{35}\right)$.

In folk culture, this kind of violence against wizards and witches who have achieved metamorphosis is meant as a defence of the 
community against the evil intentions of the magical aggressor, as well as being a punishment.

\section{The role, the activity and status of marginal characters in village society}

All informants mention that behind the wizard or witch's unfriendly acts, there is a supernatural force that pushes them. If they cannot free themselves from the negative force within, and do not feed on the living energy of other people, they will become ill and might harm their loved ones. People also say that some wizards and witches, in order not to harm people (Udm. ad'amiyez s'iyyny 'to eat, devour a person'), nourish themselves with the living energy of a plant (most often a tree), which consequently starts to wither and dry. If the wizard or the witch does not find an object towards which to turn his/her curse, they can send it to a stone, a pillar, to the wind (Minniyakhmetova 1996: 261) or to other places (a gully, the forest) (Vladykina, Glukhova 2011: 30; Anisimov 2016: 46-50). The following text is about giving the negative energy of a wizard to the wind, and how this then met my informant:

Informant 1: Töl shory zhimem shuo es' in'i, so, dyr, in'i so. Töle lez'o es' in 'i “fu-u” shusa.

Informant 2: "Uf-f”' shusa pottysa lez'o no, o-o-a. Kinly, dyr, mynsa us'e. So cherla. [...] Töl shory zhimem shuysa mone Menziyan chuzhapay emn'az. Tabayez dzh'yrdatiz, mone shobyrtis'ky shuiz, o-o-a. "Taz'y töl shory zhimem. Emez-yumez ta med lo"-vu kis'tiz. So paryn marym karis'kod. "Töl shorys' zhimem. Emez-yumez ta med luoz, med koshkoz!"-shuiz.

Informant 1: They say I met the wind, and it is true, I suppose. They let it into the wind, breathing out "fuuuu". 
Informant 2: By breathing out "uuuuf" they let it go, and get free of it, so it is. On its way it sticks probably to someone. This person gets ill. [...] Aunt Menziyan healed me saying that I met the wind. She heated a pan, asked me to cover myself, so it is. [With the words] "She met thus the wind. Let this be to her a medicine, a healing" and she spat some water. With the steam it is done [you will be healed]. "You got ill from the wind. Let this be your medicine, your healing, let it leave you" said [the aunt] (FWM $\left.{ }^{36}\right)$.

As Tatiana Vladykina and Galina Glukhova noted, “...the influence on the forest is seen as a good deed: the wizard claims he spared the people and diverted the possible misfortune" (Vladykina, Glukhova 2011: 30). But there are also contradictory data, according to which another person, who meets this tree or cuts it, can receive the illness or even die:

Faydyr agay tin'i typu pogyrtem no, cherlasa bertem no, kulem. Busy shoris'... Busy shoryn typu kyl'l'e vylem. Soye pogyrtem no püly shusa, bertem no kulem.

Uncle Faydyr cut an oak, turned, fell and died. [The oak, which grew] in the middle of the field... In the field the oak grew. He cut it for wood, went home and died (FWM $\left.{ }^{37}\right)$.

This example shows that a persen skilled in witchcraft on the one hand gets rid of the negative forces within, and on the other hand transmits them on another living being. A person who is not aware, in contact with this being in which magic force is concentrated, receives psychophysical damage.

The interviewers commented that wizards and witches are particularly active during festive periods, and most of all at funerals and commemorations of the dead (for more details, see, for example Anisimov 2017: 130-133, 195-196, 207-208). Through 
magic manipulations, they curse people using food, drinks, received clothes, hair, fingernails, etc. Therefore, if the community sees a suspicious person, people become immediately vigilant and follow his/her actions: "So tin’i lykte ke, sak karis'kono n’i. Kytyn gyne mar gyne medaz uzha shuysa", "Now, if she comes, you must be vigilant so that she does not do anything harmful" $\left(\mathrm{FWM}^{38}\right)$. If there is somebody from outside the community, people are cautious of such a hostile person. I have faced this situation myself several times during my fieldwork (2009-2021) in different Udmurt groups. When somebody suspected of being a wizard or witch arrived, I was warned not to step close, not to take anything from him/her and not to taste his/her drinks.

According to other representations, witches often quarrel and do not get along with each other. According to one women, this happens when their vedin' $k y l$, their 'witchcraft word', does not fit, provoking personal conflict (Anisimov 2021).

In the village community, where everybody knows everybody else, such a marginal person is perceived with caution and even disdain. However, according to other data, such attitudes are not unanimous:

Vedin'en yake keretysa ulono, yake tuzh tupasa.

With a wizard or a witch you must live either quarrelling, or in total harmony $\left(\mathrm{FWM}^{39}\right)$

So achiz ik vedna no, achiz ik vednamze pel'l'a val.

He caused the ailment himself and he healed it himself $\left(\mathrm{FWM}^{40}\right)$.

Thus, these marginal people are feared and avoided, although people do also turn to them for various reasons. According to Elena Zaytseva's data: "people addressed the wizard asking him to heal 
them in rare cases, when the healer could not help, particularly when the etiology of the disease revealed a curse by a powerful wizard" (Zaytseva 2003: 171). Tatiana Panina also refers to this ambiguity in the way magic specialist are treated, observing that it is particularly visible in the southern districts of Udmurtia, in comparison with the North and the Centre (Panina 2014: 84). People still consider that a curse or an illness received from a Mari wizard or healer can only be cured by a magic specialist from the same ethnic group. Moreover such a curse is considered the strongest and most difficult to cure $\left(\mathrm{FWM}^{41}\right)$. This is confirmed by healers practicing incantational healing (Anisimov 2021).

However, we can also find diametrically opposed cases. For example in Gurez'-Pudga (Vavozh district, Udmurtia) an elder healer declared that she had previously helped people, but that she has been so much disparaged and called a witch, that now everybody in the district is afraid of her and treats her like a leper $\left(\mathrm{FWM}^{42}\right)$. In Starokalmiyarovo (Tatyshly district, Bashkortostan) local people said that when quarrels and turmoil occur between the children or grandchildren of a healer and others, the healer's family threatens the other children, saying that their granny will send them illness and misfortune. According to these informants, some healers indeed curse people in order to have this person address them for healing, and thus obtain financial profit. Elena Zaytseva confirms such understandings by the Udmurt: "If she is able to cure, then she is also able to curse" (Zaytseva 2003: 171).

\section{Methods of protection from wizards and witches}

Data from recent years show that people are aware not only of traditional methods of protecting themselves against wizards and witches, but also of entirely new ones. Among the traditional methods we can mention the following: keeping an onion or piece 
of garlic handy, or a pin or breadcrumbs; pouring salt on the head (both of an adult or a child), or having salt in one's pockets; wearing on one's wrist a red thread; biting one's thumb; holding thumb and ring finger together, etc. According to folk understanding, the most efficient method of depriving a wizard or witch of their magic force is to get them to eat their own excrement, added to some dish or drink (Vladykina 1997: 241; Anisimov 2017: 69). "Therefore, they hide their own feaces; they always attempt to hide it" (Vladykina 1997: 241). If this happens, the enemy becomes weak-minded and loses his/her magic force.

Peres' kyshnomurt, pe, vednas'ke val no shusa odig kyshnomurt veraz. Sere, pe, mi soye marym, kiz'enyz l'uktam, pe, no, viz'tem kad', pe, luiz. Nomyrze no, pe, ug vala n’i.

An old woman, they say, was a witch, as one woman said. Later, they say, we did that, we gave her her [own] urine to drink, and she became like a lunatic. She does not understand anything anymore (Anisimov 2021).

According to Tatiana Vladykina, human feaces is connected with the mask of death, which is a necessary object to address representatives of the world beyond, creating a "world upside down" and thus protecting people from the inhabitants of the other world (for more details see Vladykina 1997: 310-312), with which folk understanding connects wizards and witches.

In the tradition of Christian Udmurts there are different objects and verbal texts carrying Christian symbols (holy water, objects containing prayer, crosses, icons, etc.). Some of these methods that offer protection from the influence of witchcraft when receiving guests and offering them drinks are still practiced today (Anisimov 2019: 221-223).

In order to get help against wizards and witches, people turn to healers (Udm pel'l'as'kis'lit: 'one who blows' / pel'l'as' lit: 'one who 
blows' / pel'tis' lit: 'one who blows' / tunochi 'diviner'/tuno-pel'l'o 'diviner', 'healer'/emn'es'kis' 'physician'/todis' 'one who knows' I todysh"yas'kis' 'one who deals with knowledge, with witchcraft'), who endeavour to remove the curse and protect them from future influence (Anisimov 2021).

Among newer methods to protect oneself from magic, we can mention objects from foreign cultures. We can thus find in Udmurt villages objects with apotropaic functions from Asia, Africa, India, China, Turkey and other countries of the world. These case are not mass examples, and neither are they widespread, but they happen. In most of these cases the owners of these objects do not know the exact symbolism connected to them, but they believe in their force and protective abilities.

\section{Representations and trends in recent years}

In recent years I have met tales in which informants openly acknowledge that they belong to a family in which there are wizards or witches:

Mi ved' Tash vyzhyis', Tash vyzhyez vedin' shuo val uk.

Indeed we are from the clan Tash, which was said to be a clan of wizards $\left(\mathrm{FWM}^{43}\right)$.

I must add that the informants say this without any mystery or caution whatsoever. As one of them declares, sometimes in conversation she mentions this kinship, so that possible enemies will be afraid of her. It is interesting that formerly some things were never openly said; on the contrary, people were afraid of being recognised. Udmurt ethnologist Tatiana Minniyakhmetova confirms that: “... among people it was not customary to talk openly about people possessing 'an impure force' ... people able to make miracles did 
not acknowledge it, and pretended ignorance of its very existence, but when they were reminded, they might agree with the opinion of others" (Minniyakhmetova 1996: 259). In some cases, Udmurts warn or inform others that they possess a strong magical object with the help of which they can affect others, for example, threads obtained from a pillow on which somebody died $\left(\mathrm{FWM}^{44}\right)$.

Everywhere we hear stories about the impossibility of wizards and witches flying, because there are power transmission lines everywhere today. According to the informants, they are made of metals and as we know, metal is a protection from 'impure forces'. Moreover, wires, like a spider's web, extend across a space, disturbing free movement during flights.

Oz'y shuiz in'i chuzhatay, el'ektrichestvo, dyr, mar, dyr, syshe provod"yos... el'ektroprovoda sil'no, pe, vl'iyayut sycheosly. Sekyt, pe, lue sycheosly.

Grandfather said that electricity, probably, those wires... electric wires have a huge effect on such people. It is hard, they say, to become like them $\left(\mathrm{FWM}^{45}\right)$.

There were also data according to which transmissions from mobile networks and satellite antennas are an obstacle for wizard and witch flights:

Yöz”yosles' gyne övöl, antennaos no tros uk al'i, olokytshe no tarelkaos puktylemyn. So meshat'te, yyre s'ote. [...] Vyle tubkod ke, tatyn shuom sytshe tarelka, otyn sytshe. Sooslen shorazy kytshe ke no marayzy van'... Soles' vyle tubizy ke, mozhet'lobdzh'yny bygatozy, no vr'ad l'i kyd'oke pegdzh'ozy, lobdzh'ozy. 
There are not only wires, but now also many aerials, different kinds of dish. This disturbs, it hurts their heads. [...] When you move up, and here is one dish, there another, there another yet... and in the middle there is this thing... If they manage to move higher, perhaps they are able to fly, but they will probably not be able to flee very far, to fly away $\left(\mathrm{FWM}^{46}\right)$.

Being an active Church-goer, and proclaiming dedication to Orthodoxy can also be, as my field materials reveal, a reason to suspect someone of witchcraft. According to some informants, if a person has never, or rarely, attended church, and then suddenly starts to do so, this means that this person wants to pray him or herself out of the sin of being a witch or wizard. One informant acknowledged that her neighbour actively goes to church, but she still behaves in a definitely non-Christian way: she is envious, she curses, she gossips, she sends curses. Once, the woman who told the story went to her house and saw some strange action - her neighbour was standing in front of a small open window reading something from a book. When she noticed that she had been spotted, she started cursing and she was not happy that her neighbour had come and wished her gone. This gave her grounds to give this neighbour the status of witch.

It is quite interesting to observe that some of the informants tend to think that the majority of wizards or witches are young because the young are keen on practicing different kinds of magic. According to them, the reason for this is to be found in the number of TV shows and social media groups, in the availability of books about magic and objects, etc. These informants declare that they have a bad perception of this preoccupation, and think that young people will be made to pay through different forms of misfortune. 


\section{Conclusion}

As this research shows, belief in the existence of extraordinary people is alive among the Udmurt today. The wizard or the witch, who show evidence of having relations with both worlds (this world and the world beyond), experience a contradictory attitude from the community, despite which they have a special status as people who possess supernatural force and sacred knowledge. The available folklore stories and our interviews show that along with traditional representations and knowledge, there are also new understandings. I would highlight that one of the relatively recent representations is that young people have started to deal actively with magic practice, and that among the apotropaic objects one can find objects from abroad (for example the Turkish nazar bondzhuk amulet). Many tales about wizards and witches, as well as magic practices and supernatural forces, create a picture of the modern understanding of the Udmurt village and actualise folk knowledge present in tradition. This research does not pretend to give a full picture, and I plan in the future to publish a series of articles dedicated to the question of magical specialists in Udmurt culture. The next step can be also a comparative study. Especially in the Estonian and Livonian as well as in Finnish and Swedish traditions there is a well-known image of a witch whose soul can fly, or he/she turn into different animals and birds (Loorits 1928; Loorits 1926; Kõiva, Boganeva 2020; Finnish data: Jauhiainen 1998; Swedish: Klintberg 2010).

\section{Acknowledgements}

This research has been achieved with the financial support of Estonian research grant No. PUT590 "Tänapäevane soome-ugri animism: funktsioonid ja sotsiaalne kontekst (2015-2018)", French research grant IUF "Étude interdisciplinaire d'une minorité 
animiste en Russie d'Europe, les Oudmourtes orientaux: rituels, coutumes, engagement communautaire aujourd'hui (2018-2022)", Estonian Literary Museum research grant EKM 8-2/20/3 and the Centre of Excellence in Estonian Studies (TK 145) through the European Regional Development Fund.

\section{List of the informants}

Aleksandrov, Pavel Andreevich, born 1994 in Nikolashkino, Bavly district, Tatarstan

Anisimova, Elena Fyodorovna, born 1968 in Verkhnyaya Malaya Sal'ya, Kiyasovo district, Udmurtia and living in Dubrovskiy, same district

Garaeva, Liliya Zidiyarovna, born 1953 in Bigineevo, Tatyshly district, Bashkortostan and living in Aribash, same district

Garifullina, Al'fira Vasil'yevna, born 1982 in Vyazovka, Tatyshly dstrict, Bashkortostan

Gil'manova, Nina Ganniyanovna, born 1956 in Karabashevo, Il'ishevo district, Bashkortostan and living in Yagul, Zav'yalovo district, Udmurtia

Zaytseva, Yana Leonidovna, born 1973 in Bagrash-Bigra, Malaya Purga district, Udmurtia

Kamaltdinova, Rakhima Nurislamovna, born 1948 in Novyye Tatyshly, Tatyshly district, Bashkortostan and living in Vyazovka, same district

Karabaeva, Maria Ivanovna, born 1961 in Bob’ya-Ucha, Malaya Purga district, Udmurtia and living Malaya Purga, same district

Kornilova, Alevtina Leonidovna, born 1961 in Bob’ya-Ucha, Malaya Purga district, Udmurtia

Kulikova, Zinaida Frantsovna, born 1954 in Nizhnyaya Malaya Sal'ya, Kiyasovo district, Udmurtia, and living in Staraya Sal'ya, same district

Lukina, Nadezhda Nikolaevna, born 1970 in Puro-Mozhga Malaya Purga district, Udmurtia and living in Kuregovo, same district 
Mentdiyarova, Flyura Menkairovna, born 1951 in Urazgil'dy, Tatyshly district, Bashkortostan

Nikolaeva, Anastasia Fyodorovna, born 1941 in Novaya Mon'ya, Malaya Purga district Udmurtia, and living in Bagrash-Bigra, same district

Nikonova, Maria Pavlovna, born 1926 in Nizhnyaya Malaya Sal'ya, Kiyasovo district, Udmurtia and living in Dubrovskiy, same district

Nurieva, Flyura Aynukovna, born 1960 in Bigineevo, Tatyshly district, Bashkortostan and living in Malaya Bal'zuga, same district

Nurtdinov, Sal'akhutdin Minsharaevich, born 1952 in Urazgil'dy, Tatyshly district, Bashkortostan

Nurtdinova, Madina Shaykhundinovna, born 1955 in Nizhnebaltachevo, Tatyshly district, Bashkortostan, and living in Urazgil'dy, same district

Pavlova, Galina Nikolaevna, born 1957 in Dubrovskiy, Kiyasovo district, Udmurtia and living in Staraya Sal'ya, same district

Petukhova, Raisa Ivanovna, born 1956 in Staraya Sal'ya, Kiyasovo district, Udmurtia

Riyanova, Zoia Menkairovna, born 1964 in Urazgil'dy, Tatyshly district, Bashkortostan

Sovinova, Luker'ya Kuz'movna, born 1934 in Karamas-Pel'ga, Kiyasovo district, Udmurtia

Sufiyarov, Radik Ivanovich, born 1961 in Malaya Bal'zuga, Tatyshly district, Bashkortostan

Timerkhanova, Anifa Timershinovna, born 1960 in Vyazovka, Tatyshly district Bashkortostan

Usol'tseva, Ksenia Yakovlevna, born 1931 in Dubrovskiy, Kiyasovo district, Udmurtia

Filimonova, Irina Olegovna, born 1986 in Minderovo, Malaya Purga district, Udmurtia

Chibysheva, Irina Yakovlevna, born 1946 in Bagrash-Bigra, Malaya Purga district, Udmurtia

Chibysheva, Flyura Akhmetkhanovna, born 1962 in Andreevka, Yanaul district, Bashkortostan and living in Izhevsk, Udmurtia 
Shaysultanova, Yulia Vladimirovna, born 1964 in Starokalmiyarovo, Tatyshly district, Bashkortostan and living in Malaya Bal'zyuga, same district

Shirshina, Evdokiya Ivanovna, born 1931 in Novyye Kaksi Mozhga district, Udmurtia and living in Staryye Kaksi, same district

\section{Notes}

1 Recorded from M. P. Nikonova, born 1926 in Nizhnyaya Malaya Sal'ya, Kiyasovo district Udmurtia, now living in Dubrovskiy, same district, by N. Anisimov, 2013; from R. I. Petukhova, born 1956 in Staraya Sal'ya, Kiyasovo district, Udmurtia, by N. Anisimov, 2015; from I. O. Filimonova, born 1986 in Minderovo, Malay Purga district, Udmurtia, by N. Anisimov 2015.

2 Recorded from L. G. Pukrokova, born 1960 in Starokalmiyarovo, Tatyshly district, Bashkortostan and living in Asavka, Baltachevo district, Bashkortostan, by N. Anisimov, R. Sadikov, E. Toulouze 2016.

3 Recorded from I. O. Filimonova, born 1986 in Minderovo, Malaya Purga district, Udmurtia, by N. Anisimov, 2015; recorded from N. N. Lukina, born 1970 in Puro-Mozhga, Malaya Purga district, Udmurtia and living in Kuregovo, same district, by N. Anisimov, 2017.

${ }^{4}$ Recorded from M. I. Karabaeva, born 1961 in Bob'ya-Ucha, Malaya Purga district, living in Malaya Purga, same district, by N. Anisimov, 2015.

5 Recorded from S. M. Nurtdinov, born 1952 in Urazgil'dy, Tatyshly district, Bashkortostan, by N. Anisimov, A. Baydullina, 2017.

6 Recorded from E. I. Shirshina, born 1931 in Novyye Kaksi, Mozhga district, Udmurtia and living in Staryye Kaksi, same district, by N. Anisimov, 2014.

7 Recorded from E. F. Anisimova, born in 1968 in Verkhnyaya Malaya Sal'ya, Kiyasovo district, Udmurtia and living in Dubrovskiy, same district, by N. Anisimov, 2013.

${ }^{8}$ Recorded from K. Ya. Usol'tseva, born 1931, Dubrovskiy, Kiyasovo district, Udmurtia by N. Anisimov, 2014; recorded from L. K. Sovinova, born 1934, Karamas-Pel'ga, Kiyasovo district, Udmurtia by N. Anisimov, E. Toulouze, 2017. 


\section{Nikolai Anisimov}

9 Recorded from M. P. Nikonova, born in 1926 in Nizhnyaya Malaya Sal'ya, Kiyasovo district, Udmurtia and living in Dubrovskiy, same district, by N. Anisimov, 2013; from R. I. Petukhova, born in 1956 in Staraya Sal'ya, Kiyasovo district, Udmurtia, by N. Anisimov, 2015; from I. O. Filimonova, born 1986 in Minderovo, Malaya Purga district, Udmurtia, by N. Anisimov, 2015; from L. Z. Garaeva, born 1953 in Bigineevo, Tatyshly district, Bashkortostan and living in Aribash, same district, by N. Anisimov, 2016.

${ }^{10}$ Recorded from R. I. Petukhova, born in 1956 in Staraya Sal'ya, Kiyasovo district, Udmurtia, by N. Anisimov 2015; from I. O. Filimonova, born 1986 in Minderovo, Malaya Purga district, Udmurtia, by N. Anisimov 2015; recorded from N. N. Lukina, born 1970 in Puro-Mozhga, Malaya Purga district, Udmurtia and living in Kuregovo, Malaya Purga district, Udmurtia by N. Anisimov 2017; from L. K. Sovinova, born 1934 in Karamas-Pel'ga, Kiyasovo district, Udmurtia by N. Anisimov, E. Toulouze. 2017; recorded from A. L. Kornilova, born 1961 in Bob'yaUcha, Malaya Purga district, Udmurtia, by N. Anisimov, 2018.

${ }^{11}$ Recorded from F. A. Nurieva, born 1960 in Bigineevo, Tatyshly district, Bashkortostan and living in Malaya Bal'z'uga, same district, by N. Anisimov, 2017.

${ }^{12}$ Recorded from L. K. Sovinova, born 1934 in Karamas-Pel'ga, Kiyasovo district, Udmurtia by N. Anisimov, E. Toulouze, 2017.

${ }^{13}$ Recorded from R. I. Petukhova, born 1956 in Staraya Sal'ya, Kiyasovo district, Udmurtia, by N. Anisimov, 2015.

${ }^{14}$ Recorded from Z. F. Kulikova, born 1954 in Nizhnaya Malaya Sal'ya, Kiyasovo district, Udmurtia, and living in Staraya Sal'ya, same district by N. Anisimov, 2018.

15 This informant expressed the wish to remain anonymous. Recorded by N. Anisimov, 2018.

${ }^{16}$ Inmar - the suprime heavenly God.

${ }^{17}$ This informant expressed the wish to remain anonymous. Recorded by N. Anisimov, 2009.

${ }^{18}$ Recorded from N. N. Lukina, born 1970 in Puro-Mozhga, Malaya Purga district, Udmurtia and living in Kuregovo, same district, by N. Anisimov, 2017.

${ }^{19}$ Recorded from F. A. Nurieva, born 1960 in Bigineevo, Tatyshly district, Bashkortostan and living in Malaya Bal'zuga, same district, by N. Anisimov, 2016. 
${ }^{20}$ Recorded from A. F. Nikolaeva, born 1941 in Novaya Mon'ya, Malaya Purga district, Udmurtia, and living in Bagrash-Bigra, same district, by N. Anisimov, 2016.

${ }^{21}$ This story was told in Russian. This explains the difference in transliteration.

${ }^{22}$ Recorded from S. M. Nurtdinov, born 1952 in Urazgil'dy, Tatyshly district, Bashkortostan, by N. Anisimov, A. Baydullina, L. Vallikivi, 2017.

${ }^{23}$ Recorded from F. M. Mentdiyarova, born 1951, in Urazgil'dy, Tatyshly district, Bashkortostan, by N. Anisimov, A. Baydullina, 2017.

${ }^{24}$ Recorded from R. I. Sufiyarov, born 1961 in Malaya Bal'zuga, Tatyshly district, Bashkortostan, by N. Anisimov, 2016.

${ }^{25}$ Recorded from M. I. Karabaeva, born 1961 in Bob’ya-Ucha, Malaya Purga district, Udmurtia and living in Malaya Purga, same district, by N. Anisimov, 2014.

${ }^{26}$ Recorded from Ya. L. Zaytseva (Informant 1), born 1973, and I. Ya. Chibysheva (Informant 2), born 1946, both in Bagrash-Bigra, Malaya Purga district, Udmurtia, by N. Anisimov, 2016.

${ }^{27}$ For example it is assumed that if a village is visited by a cuckoo, a squirrel or a fox, there will be soon a fire.

${ }^{28}$ Here too, the story was told in Russian.

${ }^{29}$ Recorded from M. Sh. N., born 1955 in Nizhnyeye Baltachevo, Tatyshly district, Bashkortostan, and living in Urazgil'dy, same district, by N. Anisimov, A. Baydullina, L. Vallikivi, 2017.

${ }^{30}$ Recorded from Z. M. Riyanova, born 1964 in Urazgil'dy, Tatyshly district, Bashkortostan, by N. Anisimov, A. Baydullina, 2017.

${ }^{31}$ Recorded from A. T. Timerkhanova, born 1960 in Vyazovka, Tatyshly district, Bashkortostan, by N. Anisimov, 2015.

${ }^{32}$ Recorded from M. P. Nikonova, born 1926 in Nizhnyaya Malaya Sal'ya, Kiyasovo district, Udmurtia and living in Dubrovskiy, same district, by N. Anisimov, 2015.

${ }^{33}$ Recorded from F. A. Chibysheva, born 1962 in Andreevka, Yanaul district, Bashkortostan and living in Izhevsk, Udmurtia, by N. Anisimov, 2014.

${ }^{34}$ Recorded from Yu. V. Shaysultanova, born 1964 in Starokalmiyarovo, Tatyshly district, Bashkortostan and living in Malaya Bal'zuga, same district, by N. Anisimov, 2016. 
${ }^{35}$ Recorded from L. K. Sovinova, born 1934, Karamas-Pel'ga, Kiyasovo district, Udmurtia by N. Anisimov, E. Toulouze, 2017.

${ }^{36}$ Recorded from A. V. Garifullina (Informant 1), born 1982; R. N. Kamaltdinova (Informant 2), born 1948, both in Novyye Tatyshly, Tatyshly district, Bashkortostan and living in Vyazovka, same district, by N. Anisimov, L. Vallikivi, E. Toulouze, 2017.

${ }^{37}$ Recorded from R. N. Kamaltdinova (Informant 2), born 1948 in Novyye Tatyshly, Tatyshly district, Bashkortostan and living in Vyazovka, same district, by N. Anisimov, L. Vallikivi, E. Toulouze, 2017.

${ }^{38}$ My informant wished to remain anonymous. Recorded by N. Anisimov, 2016.

${ }^{39}$ Recorded from G. N. Pavlova, born in Dubrovskiy, Kiyasovo district, Udmurtia and living in Staraya Sal'ya, by N. Anisimov, 2010.

${ }^{40}$ Recorded from A. T. Timerkhanova, born 1960 in Vyazovka, Tatyshly district, Bashkortostan, by N. Anisimov, 2015.

${ }^{41}$ Recorded from R. I. Petukhova, born 1956 in Staraya Sal'ya, Kiyasovo district, Udmurtia, by N. Anisimov, 2015.

${ }^{42}$ Here and further on, my informants wished to remain anonymous: recorded in Gurez'-Pudga, Vavozh district, Udmurtia, by N. Anisimov, 2014; Starokalmiyarovo, Tatyshly district, Bashkortostan, by N. Anisimov, L. Vallikivi, R. Sadikov, E. Toulouze 2017.

${ }^{43}$ Recorded from G. N. Pavlova, born 1957 in Dubrovskiy, Kiyasovo district, Udmurtia and living in Staraya Sal'ya, same district, by N. Anisimov, 2017.

${ }^{44}$ Recorded from P. A. Aleksandrov, born 1994 in Nikolashkino, Bavly district, Tatarstan, by N. Anisimov, 2016.

${ }^{45}$ Recorded from N. G. Gil'manova born 1956 in Karabashevo, Ilishevo district, Baxhkortostan and living in Yagul, Zav'yalovo district, Udmurtia, by N. Anisimov, 2014.

${ }^{46}$ Recorded from N. N. Lukina, born 1970 in Puro-Mozhga Malay Purga district, Udmurtia and living in Kuregovo, same district, by N. Anisimov, 2017.

\section{References}

Anisimov, N. 2016. Alama/urod in(')ty "plokhoye mesto" v etnokul'turnom landshafte udmurtov: kommunikativnyy aspekt [Alama/urod in(') ty - "bad place" in the ethnocultural landscape of the Udmurt: the communicative aspect]. In: Ezhegodnik finno-ugorskikh issledovaniy 
[Yearbook of the Finno-Ugric Studies]. Vol. 10. $3^{\text {rd }}$ ed. Izhevsk: Udmurtskiy universitet, pp. 43-50.

Anisimov, N. 2017. "Dialog mirov"v matritse kommunikativnogo povedenija udmurtov ["Dialogue of the worlds" in the matrix of communicative behaviour of the Udmurt]. Tartu: Tartu University Press.

Anisimov, N. 2019. Alkogol' v kul'ture udmurtov: otkrytyy tekst i skrytyy kontekst [Alcohol in the Culture of the Udmurts: Open Text and Hidden Context]. In: E. Popova (ed.) Napitki v kul'ture narodov UraloPovolzh'ya: kollektivnaya monografiya [Drinks in the Culture of the Peoples of the Ural-Volga Region: A Collective Monograph]. Izhevsk: Udmurtskiy institut istorii, yazyka i literatury Uralskogo otdeleniya Rossiyskoy akademii nauk, pp. 205-226.

Anisimov, N. 2021. Specialists of magic in the udmurt culture: Some portraits. Journal of Ethnology and Folkloristics [In Press].

Belova, O. 2009. Svoy - chuzhoy [The Own - the Other]. In: Slavyanskiye drevnosti: Etnolingvistichesky slovar' [Slavic Antiquities: Ethnolinguistic Dictionary]. Vol. 4. Moscow: Mezhdunarodnyye otnosheniya, pp. 581-582.

Boganeva, E., Kõiva, M. 2020. Beliefs about flying serpents in Belorusian, Estonian and Russian Estonian tradition. In: M. Maeva, Y. Erolova, P. Stoyanova, M. Hristova, V. Ivanova (ed.) Between the Worlds: Magic, Miracles and Mysticism (1-23). Sofia: Paradigma.

Jauhiainen, M. 1998. The Type and Motif Index of Finnish Belief Legends and Memorates. Folklore Fellow Communications 267. Helsinki: Academia Scientiarum Fennica.

Klintberg, B. 2011. The Types of the Swedish Folk Legend. Folklore Fellow Communications 300. Helsinki: Academia Scientiarum Fennica.

Loorits, O. 1928. Liivi rahva usund III [Livonian Folk Belief III]. Tartu: Tartu University Press.

Loorits, O. 1926. Livische Märchen und Sagenvarianten [Versions of Livonian Tales and Legends]. Folklore Fellow Communications 66. Hamina: SKS.

Panina, T. 2014. Slovo i ritual v narodnoy meditsine udmurtov: Monografiya [Word and Ritual in the Udmurt's Folk Medicine: Monograph]. Izhevsk: Udmurtskiy institut istorii, yazyka i literatury Uralskogo otdeleniya Rossiyskoy akademii nauk.

Vladykina, T. 1992. Udmurtskiye pover'ya v sisteme etnosotsial'noy reglamentatsii [Udmurt beliefs in the system of ethnosocial regulation]. In: G. Shklyayev (ed.) Traditsionnoye povedeniye i obshcheniye 
udmurtov: Sbornik statey [Traditional Behavior and Communication of Udmurt: Collection of Articles]. Izhevsk: Udmurtskiy institut istorii, yazyka i literatury Uralskogo otdeleniya Rossiyskoy akademii nauk, pp. $126-170$.

Vladykina, T. 1997. Udmurtskiy fol'klor: problemy zhanrovoy evolyutsii i sistematiki: Monografiya [Udmurt Folklore: Problems of Genre Evolution and Taxonomy. Monograph]. Izhevsk: Udmurtskiy institut istorii, yazyka i literatury Uralskogo otdeleniya Rossiyskoy akademii nauk.

Vladykina, T. 2004. Znayushchiy (tuno) v udmurtskoy traditsionnoy kul'ture [The One Who Knows (tuno) in the Udmurt Traditional Culture]. In: T. Vladykina (ed.) Udmurtskaya mifologya [Udmurt Mythology]. Izhevsk: Udmurtskiy institut istorii, yazyka i literatury Uralskogo otdeleniya Rossiyskoy akademii nauk, pp. 97-102.

Vladykina, T., Glukhova, G. 2011. Ar-god-bergan: Obryady i prazdniki udmurtskogo kalendarya [Year-Circle: Rituals and Celebrations of the Udmurt Calendar]. Izhevsk: Udmurtskiy universitet.

Zaytseva, E. 2003. Kategorii vrachevateley u udmurtov [Categories of Healers among the Udmurts]. In: Etnos - Kul'tura - Chelovek: Sb. mater. mezhdunar. nauch. konf., posv. 60-letiyu V. E. Vladykina [Ethnos - Culture - Man: Collection of Papers, Dedicated to the $60^{\text {th }}$ Anniversary of V. Vladykin]. Izhevsk: ANK, pp. 168-173.

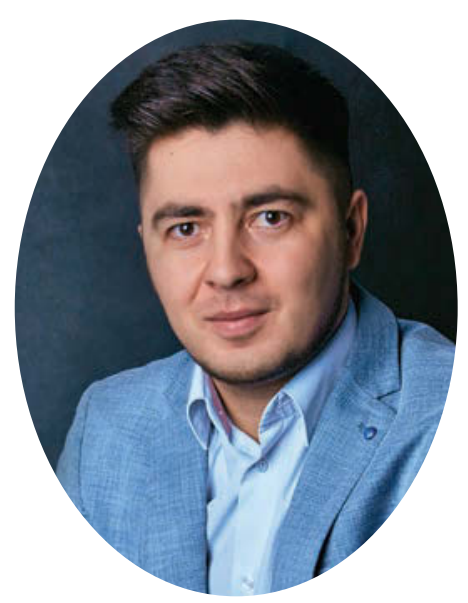

Nikolai Anisimov ( $\mathrm{PhD}$ ) is a researcher at the Department of Folkloristics at the Estonian Literary Museum, Estonia, and at the Department of Philological Studies at the Udmurt Institute for Research in History, Language and Literature (Udmurt Federal Research Centre of the Ural Branch of the Russian Academy of Sciences). His main field of interest is Udmurt traditional and contemporary culture, and more precisely, the Udmurt living ancestors' cult, and their singing tradition.

e-mail: nikolai.anisimov@folklore.ee 